\title{
Influence of environment factors on bacterial ingestion rate of the deposit-feeder Hydrobia ulvae and comparison with meiofauna
}

\author{
Pierre-Yves Pascal ${ }^{1,{ }^{*}}$, Christine Dupuy ${ }^{1}$, Pierre Richard ${ }^{1}$, Anne-Gaelle Haubois ${ }^{1}$, Nathalie \\ Niquil $^{1}$
}

${ }^{1}$ Littoral, Environnement et SociétéS (LIENSS) UMR 6250 CNRS - Université de La Rochelle, 2 Rue Olympe de Gouges, 17042 La Rochelle cedex, France

*: Corresponding author : Pascal P. Y., email address : pypascal@univ-Ir.fr

\begin{abstract}
:
Deposit feeders are able to process a considerable volume of sediment, containing large quantities of associated bacteria. However, conclusions concerning the trophic role played by benthic bacteria in marine sediments are still not fully elucidated. This study deals with bacterivory by the gastropod Hydrobia ulvae, one of the most abundant deposit-feeding species in intertidal mudflats in Western Europe. Ingestion rates of bacteria were determined during grazing experiments using ${ }^{15} \mathrm{~N}$ preenriched bacteria. Grazing experiments were performed in order to measure effects of abiotic (temperature, salinity and luminosity) and biotic (bacterial and algal abundances) factors on ingestion rates of bacteria by $H$. ulvae of an intertidal mudflat (Brouage, Marennes-Oléron, France). The mean ingestion rate of bacteria by $H$. ulvae was $1149 \mathrm{ng} \mathrm{C}$ ind $^{-1} \mathrm{~h}^{-1}$. The general trend showed a temperature effect with an optimum around $30^{\circ} \mathrm{C}$, and the assimilation rate was significantly lower at $5^{\circ} \mathrm{C}$. Bacterial assimilation did not significantly differ between salinity 18 and salinity 31 . Ingestion was the same in light and in dark conditions. Results were compared with those of other grazing experiments conducted simultaneously in similar conditions with two other grazers with different size and feeding modes: the foraminifera Ammonia tepida and a nematode community from the superficial sediment of the Brouage mudflat. $H$. ulvae and nematodes presented a feeding behavior less influenced by environmental changes than $A$. tepida. $H$. ulvae ingested bacteria at a higher rate than smaller meiofaunal grazers and seemed to have a lower ability to selectively ingest diatoms than meiofaunal grazers.
\end{abstract}

Keywords: Deposit-feeding, Hydrobia ulvae, Gastropod, Bacteria, Grazing, Environmental factors, Ammonia tepida, Nematodes, Mudflat 


\section{Introduction}

In pelagic environments, bacteria are heavily grazed and consequently play a major role in food webs (Azam et al., 1983). In the benthic environment, bacteria are generally 1000 times more abundant than in pelagic systems, reaching abundances of about 109 cells cm3 34 (Schmidt et al., 1998). However, microbial food web research in sediment is in its infancy and the trophic significance of benthic bacteria remains elusive (Review in Kemp, 1986). The deposit-feeder Hydrobia ulvae is one of the most abundant species of macrofauna inhabiting intertidal mudflats in Western Europe (Bachelet and Yacine-Kassab, 1987; Barnes, 1990; Sola, 1996). Deposit feeders typically process at least one body weight of sediment daily (Lopez and Levinton, 1987). This sediment includes highly digestible and nutritious microphytobenthos and bacteria, less digestible plant debris and completely indigestible refractory detritus (Rice and Rhoads, 1989). Diatoms have been found to be a major source of nutrition for H. ulvae (Fenchel et al., 1975; Jensen and Siegismund, 1980; Lopez and Cheng, 1983a; Bianchi and Levinton, 1984; Haubois et al., 2005a). However bacteria have also been found as food for Hydrobia species (Cammen, 1980; Jensen and Siegismund, 1980; Bianchi and Levinton, 1981; Levinton and Bianchi, 1981). Due to high abundances of $\mathrm{H}$. ulvae in intertidal mudflats, carbon flow from bacteria to snails may be a significant pathway in this type of environment. The objective of the present study was to quantify the bacterial ingestion rate of $\mathrm{H}$. ulvae and to investigate how this rate varies with abiotic (temperature, salinity and luminosity) and 
51 biotic (bacterial and algal abundance) factors. Intertidal mudflats are subject to large and 52 quick changes in many environmental factors at short time scales (circadian and tidal cycles) 53 (Guarini et al., 1997) and these variations may significantly influence snail feeding behaviour. 54 Bacterivory of $H$. ulvae was then compared to that of other grazers of different sizes and 55 feeding modes, the foraminifera Ammonia tepida and a nematode community from surficial 56 sediment of an intertidal mudflat (Brouage-Marennes Oléron-France). Bacterial ingestion of 57 both grazers have been previously described (Pascal et al., 2008b; Pascal et al., In press). All grazing experiments were performed simultaneously in similar conditions using stable isotope enriched prey $\left({ }^{13} \mathrm{C}\right.$ enriched algae and ${ }^{15} \mathrm{~N}$ enriched bacteria).

\section{Experimental procedure}

The Brouage intertidal mudflat is located in the eastern part of the Marennes-Oléron Bay (Atlantic coast of France). Meteorological conditions exhibit a strong seasonality typical of a temperate climate. Range of temperature and salinity in emerged sediments are more extreme during summer tidal cycles (Guarini et al., 1997). Minimum and maximum mud temperatures are $5^{\circ} \mathrm{C}$ and $34^{\circ} \mathrm{C}$ respectively. The maximum daily range of mud temperature due to emersion and immersion cycle reaches $18^{\circ} \mathrm{C}$ (Guarini et al., 1997). Salinity of overlaying water is controlled by the Charente River freshwater input, ranging from 25 to 35 over the year (Héral et al., 1982). Salinity of the upper layers of sediment may also decrease with rainfall. The sediment surface irradiance shifts from dark during submersion and night emersions to high levels of incident light during daytime emersions. This irradiance can reach $2000 \mu \mathrm{M}$ of photons $\mathrm{m}^{-2} \mathrm{~s}^{-1}$ (Underwood and Kromkamp, 2000). Details of numerous benthic organisms and processes are available concerning this intertidal zone (gathered in Leguerrier et al., 2003; Leguerrier et al., 2004; Degré et al., 2006). 


\section{Preparation of ${ }^{15} \mathrm{~N}$ enriched bacteria}

Superficial sediment $(1 \mathrm{~cm}$ depth) was collected on the Brouage mudflat $(45,55,074 \mathrm{~N}$; $1,06,086 \mathrm{~W})$. One $\mathrm{cm}^{3}$ of the collected sediment was added to $20 \mathrm{~cm}^{3}$ of bacterial liquid culture medium and kept in darkness for 24 hours at $13^{\circ} \mathrm{C}$. The composition of this culture medium was previously described in Pascal et al. (2008a). This primary culture was then subcultured for 24 hours under the same conditions to get approximately $2 \times 10^{9}$ cells $\mathrm{cm}^{3}$. Finally, bacteria were collected in $0.2 \mu \mathrm{m}$ filtered seawater after 3 centrifugations $(3500 \mathrm{~g}, 10$ $\mathrm{mn}, 20^{\circ} \mathrm{C}$ ), frozen in liquid nitrogen and kept frozen at $-80^{\circ} \mathrm{C}$ until grazing experiments.

\section{Preparation of ${ }^{13}$ C enriched algae}

An axenic clone of the diatom Navicula phyllepta (CCY 9804, Netherlands Institute of Ecology NIOO-KNAW, Yerseke, The Netherlands), the most abundant diatom species in the study area (Haubois et al., 2005b), was cultured in medium described by Antia and Cheng (1970) and containing $\mathrm{NaH}^{13} \mathrm{CO}_{3}(4 \mathrm{mM})$. Diatoms were concentrated by centrifugation $\left(1500 \mathrm{~g}, 10 \mathrm{mn}, 20{ }^{\circ} \mathrm{C}\right)$, washed three times to remove the ${ }^{13} \mathrm{C}$-bicarbonate, and freeze-dried.

\section{Quantification of bacteria and algae abundance}

In order to determine the ratio between enriched and non-enriched preys in microcosms, abundances of bacteria and algae were assessed. To separate bacteria from sediment particles, incubation in pyrophosphate $(0.01 \mathrm{M}$ for at least $30 \mathrm{~min})$ and sonication $(60 \mathrm{~W})$ were performed. Bacteria from both sediment and culture were labelled using 4.6-diamidino-2phenylindole dihydrochloride (DAPI) $\left(2500 \mu \mathrm{g} \mathrm{l^{-1 }}\right)$, filtered onto $0.2 \mu \mathrm{m}$ Nucleopore black filter (Porter and Feig, 1980) and then counted by microscopy. We verified the absence of ciliates and flagellates in the bacterial culture during this microscope observation step. The abundance of diatoms in the sediment was assessed using Chl $a$ as a proxy, measured using fluorometry (Lorenzen, 1966).

\section{Grazing experiments}


The top centimeter of sediment was collected during ebb tide from the same study area at midday on March 13, 2006. It was sieved on $500 \mu \mathrm{m}, 200 \mu \mathrm{m}$ and $50 \mu \mathrm{m}$ in order to concentrate respectively $H$. ulvae, A. tepida and nematodes. Before sieving, snails were placed on natural sediment and kept for $24 \mathrm{~h}$ at $20^{\circ} \mathrm{C}$ in the dark. Time between sieving and

104 the start of the grazing experiment never exceeded two hours in order to avoid starvation bias 105 in feeding behavior (Calow, 1975). Seventeen handpicked specimens of $H$. ulvae were placed 106 in polypropylene Petri dishes $(\varnothing=9 \mathrm{~cm})$. This density was chosen in order to avoid a density107 dependence effect on the individual ingestion due to space limitation (Blanchard et al., 2000). 108 A fraction of the sediment passing through the $50 \mu \mathrm{m}$ mesh was mixed with the ${ }^{15} \mathrm{~N}$ enriched 109 bacteria. This slurry contained $10.5 \times 10^{8}$ bacteria $\mathrm{cm}^{3},{ }^{15} \mathrm{~N}$ enriched bacteria being twice as 110 abundant as non-enriched ones. Four $\mathrm{cm}^{3}$ of this slurry were put into each microcosm. Each 111 experiment was carried out in triplicate, along with at least one control. Control samples were 112 frozen $\left(-80^{\circ} \mathrm{C}\right)$ in order to kill any grazers.

113 The calculation of bacterial ingestion rate relies on the assumption that enriched preys 114 accumulate in snail's gut at a constant rate, and that no egestion of labelled materials occurs 115 during incubation time. A kinetic study was run for 1 to 12 hours including the 2 hour run that 116 was used for all other experiments. Incubations were made under the following standardized 117 conditions that were close to the mean values recorded on the study site: temperature $\left(20^{\circ} \mathrm{C}\right)$, 118 salinity (31), luminosity (darkness), bacterial abundance $\left(10.5 \times 10^{8}\right.$ bacterial cells $\left.\mathrm{cm}^{3}\right)$ and 119 algal abundance $\left(15 \mu \mathrm{gChla} g\right.$ dry sediment $\left.{ }^{-1}\right)$. For each experiment to determine the effects 120 of environmental factors, only one incubation factor was modified so as to determine its effect 121 on $H$. ulvae's grazing activity. After the sieving step, snails were transferred without 122 acclimation into different microcosms to simulate short-term changes of environmental 123 factors. To test the effect of temperature, the snails were placed at $5^{\circ} \mathrm{C}, 15^{\circ} \mathrm{C}, 30^{\circ} \mathrm{C}$ and $40^{\circ} \mathrm{C}$ : 124 these temperatures are in the range of those measured in the study area (Guarini et al., 1997). 
125 The effect of salinity was investigated by placing Hydrobia in microcosms with a salinity of

126 18. To decrease salinity, cultured bacteria were rinsed with $0.2 \mu \mathrm{m}$ filtered-sea-water diluted with $0.2 \mu \mathrm{m}$ filtered distilled water. Such decrease in salinity can occur in field conditions when sediment is exposed to heavy rainfall. The light effect was tested with a light intensity of $83 \mu \mathrm{M}$ of photons $\mathrm{m}^{-2} \mathrm{~s}^{-1}$. Bacterial abundance was modified adding various quantities of

130 bacteria enriched in ${ }^{15} \mathrm{~N}$. Bacterial abundances (total enriched and non-enriched) tested were 4, 7 and 17 cells $\mathrm{cm}^{3}$ wt $\mathrm{sed}^{-1}$ with respectively the following ratio between abundance of total and enriched bacteria: 6.1, 2.0 and 1.3. Algal abundance was modified by adding various

133 quantities of cultured $N$. phyllepta enriched in ${ }^{13} \mathrm{C}$ while bacterial abundances (total enriched 134 and non-enriched) were kept constant at $10 \times 10^{8}$ cells $\mathrm{cm}^{3}$. Algal abundance (total enriched 135 and non-enriched) were 26,64 and $114 \mu \mathrm{gChla} g$ dry sed $^{-1}$ with respectively the following 136 ratio between abundance of total and enriched algae: $2.4,1.3$ and 1.2.

137 Incubations were stopped by freezing microcosms at $-80^{\circ} \mathrm{C}$. Samples were thawed and $H$. 138 ulvae were separated by hand from their shell and the 17 specimens of each microcosm were 139 pooled and homogenized using a Potter-Eveljhem.

$140 \quad$ Isotope analysis and calculations

$141 \quad \delta^{15} \mathrm{~N}$ and $\delta^{13} \mathrm{C}$ of prey (bacteria and algae) and grazers were measured using an EA-IRMS

142 (Isoprime, Micromass, UK). Nitrogen isotope composition is expressed in the delta notation $143\left(\delta^{15} \mathrm{~N}\right)$ relative to air $\mathrm{N}_{2}: \delta^{15} \mathrm{~N}=\left[\left(\left({ }^{15} \mathrm{~N} /{ }^{14} \mathrm{~N}\right)_{\text {sample }} /\left({ }^{15} \mathrm{~N} /{ }^{14} \mathrm{~N}\right)\right.\right.$ reference $\left.)-1\right] \times 1000$. Carbon isotope 144 composition is expressed in the delta notation $\left(\delta^{13} \mathrm{C}\right)$ relative to Vienna Pee Dee Belemnite 145 (VPDB): $\delta^{13} \mathrm{C}=\left[\left(\left({ }^{13} \mathrm{C} /{ }^{12} \mathrm{C}\right)_{\text {sample }} /\left({ }^{13} \mathrm{C} /{ }^{12} \mathrm{C}\right)_{\text {reference }}\right)-1\right] \times 1000$.

146 Incorporation of ${ }^{15} \mathrm{~N}$ is defined as excess above background ${ }^{15} \mathrm{~N}$ (control experiment) and 147 is expressed in terms of specific uptake $(I) . I$ was calculated as the product of excess ${ }^{15} \mathrm{~N}(E)$ 148 and biomass of $\mathrm{N}$ per grazer. $I$ was converted to bacterial carbon grazed using the $\mathrm{C} / \mathrm{N}$ ratio of 149 bacteria. $E$ is the difference between the background $\left(F_{\text {background }}\right)$ and the sample $\left(F_{\text {sample }}\right){ }^{15} \mathrm{~N}$ 


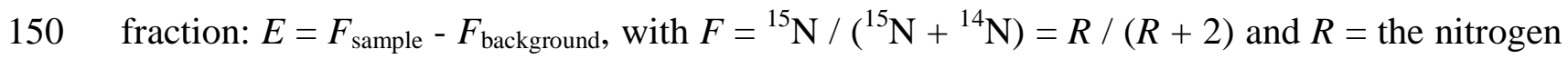

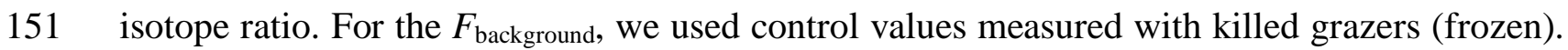

152 For $H$. ulvae we used the highest value measured in control $\left(\delta^{15} \mathrm{~N}=12.42\right.$ and $\left.\delta^{13} \mathrm{C}=-13.72\right)$.

$153 R$ was derived from the measured $\delta^{15} \mathrm{~N}$ values as: $R=\left(\left(\delta^{15} \mathrm{~N} / 1000\right)+1\right) \times R$ airN ${ }_{2}$ where $R$ airN $\mathrm{N}_{2}$

$154=7.35293 \times 10^{-3}($ Mariotti, 1982). The uptake of bacteria was calculated as Uptake $=(I \times(\%$

$\left.\left.\mathrm{C}_{\text {enriched bacteria }} / \% \mathrm{~N}_{\text {enriched bacteria }}\right)\right) /\left(F_{\text {enriched bacteria }} \times\right.$ incubation time). This uptake was

multiplied by the ratio between the abundance of total and enriched bacteria determined by

157 DAPI counts.

158 Incorporation of ${ }^{13} \mathrm{C}$ was calculated analogously, with $F={ }^{13} \mathrm{C} /\left({ }^{13} \mathrm{C}+{ }^{12} \mathrm{C}\right)=R /(R+1)$,

$159 R$ airN 2 is replaced by $R_{\mathrm{VPDB}}=0.0112372$ and Uptake $=I /\left(F_{\text {enriched bacteria }} \times\right.$ incubation time $)$.

160 The uptake measured was multiplied by the ratio between the abundance of total and enriched

161 diatom, determined from fluorometrical measurements.

162 Enriched $N$. phyllepta carbon consisted of $22.95 \pm 0.54 \%{ }^{13} \mathrm{C}$. The $\mathrm{C} / \mathrm{N}$ ratio of enriched 163 bacteria was 3.49 and bacterial nitrogen consisted of $2.88 \pm 0.03 \%{ }^{15} \mathrm{~N}$. The individual 164 average weight of $H$. ulvae was $0.54 \pm 0.08 \mathrm{mg}$ and each specimen was composed on average 165 of $184 \pm 19 \mu \mathrm{gC}$ and $43 \pm 4 \mu \mathrm{gN}(\mathrm{N}=72$ samples of at least 17 specimens each). Ingestion 166 rate as $\mathrm{gC}_{\text {bacteria }} \mathrm{gC}_{\text {H. ulvae }}{ }^{-1} \mathrm{~h}^{-1}$ was obtained by dividing ingestion rate of bacteria $\left(\mathrm{gC} \mathrm{ind}^{-1} \mathrm{~h}^{-1}\right)$ 167 by $H$. ulvae mean weight $\left(\mathrm{gC}\right.$ ind $\left.^{-1}\right)$.

168 Variations of uptake rates according to salinity and irradiance were tested using bilateral 169 independent-samples two-tailed tests. One-way analyses of variance (ANOVA) were used in 170 order to test the impact of temperature and algal and bacterial abundance on uptake rates of 171 bacteria and algae. The Tukey test was used for post-hoc comparisons.

\section{Results}

173 The kinetic experiment showed that accumulation of bacteria in $H$. ulvae increased linearly

174 during the first two hours of incubation and then levelled off (Fig. 1). The linear regression 


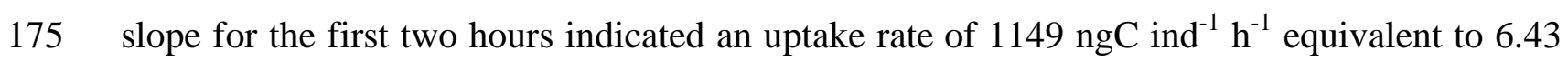

$17610^{-3} \mathrm{gC}_{\text {bacteria }} \mathrm{gC}_{H}$. ulvae $\mathrm{h}^{-1}\left(\mathrm{r}^{2}=0.98\right)$. The linear regression slope between five and twelve

177 hours was more than seven times lower than for the two first hours and indicated an uptake 178 rate of $145 \mu \mathrm{gC}$ ind $^{-1} \mathrm{~h}^{-1}$ equivalent to $0.8110^{-3} \mathrm{gC}_{\text {bacteria }} \mathrm{gC}_{\text {H. ulvae }} \mathrm{h}^{-1}\left(\mathrm{r}^{2}=0.98\right)$.

179 Ingestion of bacteria increased from 462 to $1277 \mathrm{ngC} \mathrm{ind}^{-1} \mathrm{~h}^{-1}$ when temperature increased 180 from $5^{\circ} \mathrm{C}$ to $30^{\circ} \mathrm{C}$, and then decreased reaching $1059 \mu \mathrm{gC}$ ind $^{-1} \mathrm{~h}^{-1}$ at $40^{\circ} \mathrm{C}$ (Fig. 2). Ingestion 181 rate of bacteria by $H$. ulvae was significantly decreased at $5^{\circ} \mathrm{C}(F=10 ; \mathrm{p}<0.01)$, but ingestion 182 rates observed at $10,20,30$ and $40^{\circ} \mathrm{C}$ were not significantly different.

183 The ingestion rate measured for a salinity of $31\left(1149 \pm 285 \mathrm{ngC} \mathrm{ind}^{-1} \mathrm{~h}^{-1}\right)$ was similar to 184 the one measured for a salinity of $18\left(1085 \pm 58 \mathrm{ngC} \mathrm{ind}^{-1} \mathrm{~h}^{-1}\right)($ two-tailed test, $\mathrm{p}=0.20)$.

185 The ingestion rate observed under light conditions $\left(1478 \pm 246 \mathrm{ngC} \mathrm{ind}^{-1} \mathrm{~h}^{-1}\right)$ was similar 186 to the one observed in darkness $\left(1149 \pm 285 \mathrm{ngC} \mathrm{ind}^{-1} \mathrm{~h}^{-1}\right)($ two-tailed test, $\mathrm{p}=0.72)$.

187 Ingestion rates of bacteria were significantly linked to bacterial abundance in microcosms $188(F=38 ; \mathrm{p}<0.001)$ (Fig. 3). Ingestion rate increased linearly from $38 \pm 13$ to $1117 \pm 93 \mathrm{ngC}$ $189 \mathrm{ind}^{-1} \mathrm{~h}^{-1}$ ) when bacterial concentrations increased from 4 to $10 \times 10^{8}$ cells $\mathrm{cm}^{3}$ and increased, 190 though not significantly to $1604 \pm 366 \mathrm{ngC} \mathrm{ind}^{-1} \mathrm{~h}^{-1}$ for a bacterial concentration of $17 \times 10^{8}$ 191 cells $\mathrm{cm}^{3}$.

192 Dual labeling of prey allowed simultaneous assessment of the ingestion of bacteria and 193 algae. When algal concentration increased from 15 to $114 \mu \mathrm{gChla} \mathrm{g}^{-1}$ with constant bacterial 194 abundance $\left(10.5 \times 10^{8}\right.$ cells $\left.\mathrm{cm}^{3}\right)$, the ingestion rate of algae remained constant $(\mathrm{F}=3.3 ; \mathrm{p}=$ 195 0.11) (Fig. 4). However, ingestion rate of bacteria remained constant for algal concentration 196 in the sediment between 15 and $64 \mu \mathrm{gChla} g$ dry wt sed ${ }^{-1}$ but significantly decreased at the 197 highest algal concentration of $114 \mu \mathrm{gChla} g$ dry wt $\operatorname{sed}^{-1}(\mathrm{~F}=4.4 ; \mathrm{p}<0.05)$. As a result, when 198 algal abundance increased, the fraction of algae in the diet of $H$. ulvae increased. 

foraminifera A. tepida and a nematode community. Feeding behaviour of A. tepida (Pascal et al., 2008b) and nematodes (Pascal et al., In press) has been previously described. All grazing incubations were conducted at the same time and in similar conditions, making comparisons between grazers possible. The effects of environmental factors (temperature, salinity and

204 luminosity) on ingestion rates of bacteria are summarized in Table 1. Among the different 205 grazers tested, A. tepida was the most affected by salinity and temperature. Light only affected nematodes and increased their feeding activity. Classification of grazers according to their maximal ingestion rates of bacteria and algae reported per grazer weight gave the following list arranged in ascending order: A. tepida, nematode community and H. ulvae

209 (Table 1). For the dual labelling experiment, ratios between algae and bacteria ingested were 210 measured for each grazer, at each algal concentration. Comparison of those ratios between 211 grazers reflected their respective ability to discriminate between food sources (i.e. algae and 212 bacteria). At the three algal concentrations tested, A. tepida and nematodes showed a higher 213 ratio of algae:bacteria ingested than $H$. ulvae, suggesting a better ability to preferentially 214 ingest algae over bacteria compared to the gastropod (Fig. 5).

\section{Discussion}

\section{Kinetic experiment}

217 During the 12 hour incubation, H. ulvae first accumulated the enriched bacteria linearly 218 over 2 hours (Fig. 1). This suggests that ingestion rate of bacteria was constant and that no 219 egestion of recently ingested labelled material occurred during this period. After 4 hours of 220 incubation, the accumulation rate of bacteria by $H$. ulvae decreased. This may have two 221 nonexclusive origins: egestion of labelled bacteria and a decrease in feeding activity over 222 time. As all other grazing experiments were performed during two hours, they consequently reflected the ingestion rates of $H$. ulvae. 
Linear accumulation of labelled diatom or bacteria by $H$. ulvae had been previously recorded from 45 min (Fenchel et al., 1975) to 2 hours (Blanchard et al., 2000; Haubois et al., 2005a). Molluscs have complex digestive tracts allowing partitioning of food particles within the gut. Relatively indigestible material passes quickly to the intestine and is subjected to extracellular digestion. More nutritious material like bacteria and algae is diverted to the digestive gland where it undergoes intracellular digestion. For Hydrobia totteni, gut residence 230 time is 30-40 min (Lopez and Cheng, 1983b) whereas digestive gland residence time is 5 hours (Kofoed et al., 1989). Assuming a similar situation for H. ulvae, the absence of egestion during the two hour long incubations would mean that all bacteria are diverted to the digestive gland. In their grazing experiment with enriched diatoms, Sokolowski et al. (2005) observed 234 that during the first $4 \mathrm{~h}$ phase of experiment, accumulation rate was 3 times higher than 235 during the last $12 \mathrm{~h}$ phase. We observed exactly the same ratio between accumulation rates 236 found during the grazing periods $0-2 \mathrm{~h}$ and $0-12 \mathrm{~h}$. Those similar results suggest that digestive 237 processes for bacteria and algae may be similar.

To our knowledge, there is no data dealing with the ingestion rate of bacteria by Hydrobia 240 to compare with our values. However, concerning algal ingestion our data are consistent with 241 those previously measured. In the present study, ingestion rates fluctuated between 1.2-1.8 $242 \mu \mathrm{gC}$ ind $^{-1} \mathrm{~h}^{-1}$. In the literature, ingestion rates of snails fed with diatoms are $0.5-2.9 \mu \mathrm{gC}$ ind $^{-1}$ $243 \mathrm{~h}^{-1}$ for Hydrobia truncata (Forbes and Lopez, 1989) and 1.2 (Sokolowski et al., 2005), 1.122441.33 (Blanchard et al., 2000) and 0.04-2.08 (Haubois et al., 2005a) for H. ulvae.

245 The maximal ingestion rates of algae and bacteria by Hydrobia ulvae were higher than 246 meiofaunal rates. Nevertheless, individual weight of $H$. ulvae is more than one hundred and 247 one thousand times higher than A. tepida and nematodes respectively (Table 1). Body size is 248 an important determinant of many physiological processes and maximal ingestion rate is 
generally inversely correlated to body size (e. g. Moloney and Field, 1989). The present study

250 focuses only on two potential prey, bacteria and algae, although other food sources are 251 available in sediment. For instance Dissolved Organic Material may constitute an important 252 food supply for nematodes (Lopez et al., 1979; Meyer-Reil and Faubel, 1980; Montagna, 253 1984; Jensen, 1987) and foraminifera (Schwab and Hofer, 1979). Nematodes and foraminifera 254 may be principally dependent on those other resources and present consequently low 255 ingestion rates of bacteria and algae.

\section{Effect of abiotic factors on bacterial ingestion rate}

The general trend showed a temperature effect with an optimum around $30^{\circ} \mathrm{C}$. However, except at the lowest temperature $\left(5^{\circ} \mathrm{C}\right)$, differences between feeding rates of $H$. ulvae 259 observed in the present study were not significant, indicating a limited influence of 260 temperature. In a similar manner, Barnes (2006) did not detect changes in feeding activity of H. ulvae during in situ experiments with the same range of temperature. Ingestion rates observed at salinities of 18 and 31 were not significantly different in the present study.

Grudeno \& André (2001) also observed that shell growth of juvenile. H. ulvae was unaffected

264 by salinity in the range of 15-30. Light did not affect the ingestion of bacteria by H. ulvae.

265 The literature gives conflicting results concerning the effect of light. Barnes (1986) found that crawling activity of snails was higher in darkness whereas Orvain \& Sauriau (2002) observed

267 an increase of $H$. ulvae crawling activity with light. However in Orvain \& Sauriau's 268 experiment, light may have induced formation of algal biofilm, affecting microphytobenthic 269 distribution and thus indirectly affecting snail activity levels.

270 In intertidal mudflats, the surficial centimeter of sediment is subjected to fast and large 271 environmental variations. The ability of a grazer to sustain feeding activity when 272 environmental conditions fluctuate can be interpreted as an adaptation to this habitat. All 273 compared grazers in the present study came from the top centimeter of sediment of the same 
274 study area and grazing incubations were performed in similar conditions. Compared to other 275 grazers, the feeding response of the foraminifera A. tepida presented the largest ranges of 276 variation indicating that they may present a low adaptation to rapid environmental changes 277 (Table 1). Nevertheless, A. tepida is considered as one of the most tolerant species of 278 foraminifera to temperature and salinity variations (Bradshaw, 1961; Walton and Sloan, 1990) 279 and more generally to environmental changes (Samir, 2000; Armynot du Chatelet et al., 2004; 280 Bouchet et al., 2007). A. tepida may be able to survive starvation when the environment is 281 unfavourable and may await optimal conditions to feed and develop. An alternate explanation 282 could be that when conditions are hostile, foraminifera move from the top layers of sediment 283 to deeper layers (Severin and Erskian, 1981; Severin, 1987; Groß, 2002). Feeding activity of 284 nematodes and $H$. ulvae appeared to be more independent of environmental variables. The 285 nematode community was mainly composed of three species, Chromadora macrolaima, 286 Daptonema oxycerca and Ptycholaimellus jacobi (Pascal et al., In press), known to dwell and feed in surface sediment. Moreover, H. ulvae is considered the most environmentally tolerant of Northwest European Hydrobia (Hylleberg, 1975; Lassen and Kristensen, 1978). However 289 caution must be taken in interpretation of our results because the effects of each 290 environmental factor on feeding behaviour of snails were studied independently whereas in natural environment, all these factors covary. Moreover, seasonal acclimatising capacity was 292 not taken into account (Barnes, 2006).

\section{Feeding response to bacterial and algal abundances}

294 In fine grained environments, Hydrobia ingests mouthfuls of sediment containing organic 295 food source, including bacteria and microalgae (Kofoed, 1975; Lopez and Cheng, 1983b; 296 Levinton et al., 1984). Due to high size and feeding mode of H. ulvae, the snail probably has a 297 very low ability to ingest selectively very small preys such as bacterial cells. In opposition, 
larger preys such as diatom cells can be selectively ingested from sediment by Hydrobia 299 (Fenchel, 1975; Lopez and Levinton, 1978; Lopez and Kofoed, 1980).

300 Indiscriminant ingestion of bacteria by $H$. ulvae implies that bacterial ingestion is 301 exclusively dependent on ingestion rate of sediment and the concentration of bacteria in 302 sediment. This type of feeding indicates that relationships between bacterial ingestion and 303 bacterial concentration in sediment can be described by (i) a power law relation, (ii) a linear 304 increase or (iii) null or decreasing relation. Those relations mean that when prey concentration 305 increases, ingestion rate of sediment respectively (i) increases, (ii) remains constant or (iii) decreases. In the present study, the ingestion rate of bacteria first increased linearly with bacterial concentration and then levelled off at the highest concentration (Fig. 3). This relation 308 may involve a constant ingestion rate of sediment at the lowest concentration of bacteria and a 309 decrease of ingested sediment at the highest bacterial concentration.

310 Ingestion of algae by snails was not influenced by algal concentration in the range of 311 concentration tested (Fig. 4). Contrarily, Hydrobia had been found previously to have 312 increasing algal ingestion rate when algal concentration increased in a similar range of values 313 (Forbes and Lopez, 1986; Forbes and Lopez, 1989; Haubois et al., 2005a). The ability of a 314 deposit feeder to alter its ingestion rate depends on its sensory capacity to recognize food 315 quality (Taghon, 1982). This perception may differ between the freeze-dried diatoms in the 316 present study and live diatoms in other studies, which could explain the different responses 317 observed.

318 The ratio between algae and bacteria ingested denotes grazer ability to select diatoms from 319 the sediment/bacteria aggregate. At each algal concentration, this ratio was always higher for 320 A. tepida and nematodes, indicating higher algal selection efficiency. The nematode 321 community was composed mainly of epigrowth feeders (75\%) and non selective deposit 322 feeders $(21 \%)$. Epigrowth feeders puncture diatom cells with their teeth to ingest cell 
contents. Consequently, they are mainly dependant on algal resources (Jensen, 1987). A. tepida uses a network of pseudopodia to gather and ingest food particles. This feeding mode allows foraminifera to be highly selective in ingested food (Lee et al., 1966; Lee and Muller, 1973). Ammonia may also greatly depend on algal resources, as this foraminifera was found to ingest rapidly and with high efficiency fresh algal deposits (Moodley et al., 2000). Montagna and Yoon (1991) also observed that nematodes demonstrate a high efficiency in selective ingestion of algae in comparison with other meiofaunal groups. $H$. ulvae appeared less proficient in algal selection than meiofaunal grazers. N. phyllepta, the algal species used in the present study may have been too small $(<30 \mu \mathrm{m})$ to allow selective ingestion by $H$. ulvae, but this hypothesis can reasonably be rejected as Hydrobia is not able to select diatoms according to the cell size (Levinton, 1987; Haubois et al., 2005a). In sandy sediment, Hydrobia presents epipsammic browsing activity by taking particles into the buccal cavity, scraping off attached microorganisms and then spitting out the particles (Lopez and Kofoed, 1980). As a result, gut contents and even fecal pellets of Hydrobia can contain more diatoms than the offered sandy sediment (Fenchel et al., 1975; Lopez and Levinton, 1978). Conversely, in fine grained sediment, Hydrobia ingests mouthfuls of sediment containing organic food, including microalgae (Kofoed, 1975; Lopez and Cheng, 1983b; Levinton et al., 1984). Results of the present study also suggest that $H$. ulvae feeding on muddy sediment present a limited ability to discriminate between algae and the sediment/bacteria aggregate. Taghon and Jumars (1984) pointed out that for animals having limited particle selection ability, foraging strategies are mainly a function of ingestion and digestion processes. Indeed, in the present study $H$. ulvae appeared to decrease the rate of ingested sediment at high algal and bacterial concentrations. In the present study, labelled prey were distributed homogeneously in sediment. Feeding rates and feeding behaviour of $H$. ulvae may be different when algae are condensed in biofilm. 
In the Brouage mudflat, $H$. ulvae and meiofauna are present, on average, in similar

biomasses throughout the year (Degré et al., 2006). The present study suggests that $H$. ulvae

ingests bacteria at a higher rate than meiofaunal do. In the study area, benthic bacteria would

therefore be grazed to a higher extent by macrofauna than by meiofauna.

352

353

354

355

356

\section{Acknowledgements}

We thank Amélie Sallon for her help in sample preparation, Gaël Guillou for isotopic analyses and Utte Wollenzien from NIOO-CEMO for giving us a Navicula phyllepta strain.

We are grateful to Johnson Galen for English corrections. The "Conseil Général de Charente Maritime", the programme ECCO, the programme PNEC - Chantier Littoral Atlantique and the ANR-VASIREMI financially supported this work.

\section{References}

Antia N.J., Cheng J.Y., 1970. The survival of axenic cultures of marine phytoplankton algae from prolonged exposure to darkness at $20^{\circ} \mathrm{C}$. Phycologia 9, 179-183.

Armynot du Chatelet E., Debenay J.-P., Soulard R., 2004. Foraminiferal proxies for pollution monitoring in moderately polluted harbors. Environ. Pollut. 127, 27-40.

Azam F., Fenchel T., Field J.G., Gray J., Meyer-Reil L.A., Thingstad F., 1983. The ecological role of water-column microbes in the sea. Mar. Ecol. Prog. Ser. 10, 257-263.

Bachelet G., Yacine-Kassab M., 1987. Post-recruitement phase population dynamics of the intertidal gastropod Hydrobia ulvae (Pennant). J. Exp. Mar. Biol. Ecol. 111, 37-60.

Barnes R.S.K., 1986. Daily activity rythms in the intertidal Gastropod Hydrobia ulvae (Pennant). Est. Coast. Mar. Sci. 22, 325-334.

Barnes R.S.K., 1990. Reproductive strategies in contrasting populations of the coastal gastropod Hydrobia ulvae: longevity and life-time egg production. J. Exp. Mar. Biol. Ecol. 138, 183-200.

Barnes R.S.K., 2006. Variation in feeding rate of the intertidal mudsnail Hydrobia ulvae in relation to the tidal cycle. Mar. Ecol. 27, 154-159.

Bianchi T.S., Levinton J.S., 1981. Nutrition and food limitation of deposit-feeders. II. Differential effects of Hydrobia totteni and Ilyanassa obsoleta on the microbial community. J. Mar. Res. 39, 547-556.

Bianchi T.S., Levinton J.S., 1984. The importance of the microalgae, bacteria and particulate organic matter in the somatic growth of Hydrobia totteni. J. Mar. Res. 42, 431-433.

Blanchard G.F., Guarini J.M., Provot L., Richard P., Sauriau P.-G., 2000. Measurement of ingestion rate of Hydrobia ulvae (Pennant) on intertidal epipelic microalgae: the effect of mud snail density. J. Exp. Mar. Biol. Ecol. 255, 247-260.

Bouchet V.M.P., Debenay J.-P., Sauriau P.-G., Radford-Knoery J., Soletchnik P., 2007. Effects of short-term environmental disturbances on living benthic foraminifera during the Pacific oyster summer mortality in the Marennes-Oléron Bay (France). Mar. Environ. Res. 64, 358-383. 
Bradshaw J.S., 1961. Laboratory experiment on the ecology of foraminifera. Contr. Cushman. Found. Res. 12, 87-106.

Calow P., 1975. The feeding strategies of two freshwater gastropods. Ancylus fluviatilis Mull. and Planorbis contortus Linn. (Pulmonata) in terms of ingestions rates and absorption efficiencies. Oecologia 20, 33-49.

Cammen L.M., 1980. Ingestion rate: an empirical model for aquatic deposit feeders and detritivores. Oecologia 44, 303-310.

Degré D., Leguerrier D., Armynot du Chatelet E., Rzeznik-Orignac J., Auguet J.-C., Dupuy C., Marquis E., Fichet D., Struski C., Joyeux E., Sauriau P.-G., Niquil N., 2006. Comparative analysis of the food webs of two intertidal mudflats during two seasons using inverse modelling: Aiguillon Cove and Brouage Mudflat, France. Est. Coast. Shelf. Sci. 69, 107-124.

Fenchel T., 1975. Character displacement and coexistance in mud snails (Hydrobiidae). Oecologia 20, 19-32.

Fenchel T., Kofoed L.H., Lappalainen A., 1975. Particle size-selection of two deposit feeders: the Amphipod Corophium volutator and the Prosobranch Hydrobia ulvae. Mar. Biol. 30, 119-128.

Forbes V.E., Lopez G.R., 1986. Changes in feeding and crawling rates of Hydrobia truncata (Prosobranchia: Hydrobiidae) in response to sedimentary chlorophyll a and recently egested sediment. Mar. Ecol. Prog. Ser. 33, 287-294.

Forbes V.E., Lopez G.R., 1989. The role of sediment particle size in nutritional energetics of a surface deposit-feeder. I. Ingestion and absorption of sedimentary microalgae by Hydrobia truncata (Vanatta). J. Exp. Mar. Biol. Ecol. 126, 181-192.

Groß O., 2002. Sediment interactions of foraminifera: implications for food degradation and bioturbation processes. J. Foraminifer. Res. 32, 414.

Grudemo J., André C., 2001. Salinity dependence in the marine mud snails Hydrobia ulvae and Hydrobia ventrosa. J. Mar. Biol. Ass. U. K. 81, 651-654.

Guarini J.M., Blanchard G.F., Gros P., Harrison S.J., 1997. Modeling the mud surface temperature on intertidal flats to investigate the spatio-temporal dynamics of the benthic microalgal photosynthetic capacity. Mar. Ecol. Prog. Ser. 153, 25-36.

Haubois A.G., Guarini J.M., Richard P., Fichet D., Radenac G., Blanchard G.F., 2005a. Ingestion rate of the deposit-feeder Hydrobia ulvae (Gastropoda) on epipelic diatoms: effect of cell size and algal biomass. J. Exp. Mar. Biol. Ecol. 317, 1-12.

Haubois A.G., Sylvestre F., Guarini J.M., Richard P., Blanchard G.F., 2005b. Spatio-temporal structure of the epipelic diatom assemblage from an intertidal mudflat in MarennesOléron Bay, France. Est. Coast. Shelf. Sci. 64, 385-394.

Héral M., Razet D., Deslous-Paoli J.M., Bertome J.P., Garnier J., 1982. Caractéristiques saisonnières de l'hydrologies du complexe estuarien de Marennes-Oléron (France). Revue des travaux de l'institut des pêches maritimes 46, 97-119.

Hylleberg J., 1975. The effect of salinity and temperature on egestion in mud snails (Gastropoda: Hydrobiidae). A study in niche overlap. Oecologia 21, 279-289.

Jensen K.T., 1987. Feeding ecology of free-living aquatic nematodes. Mar. Ecol. Prog. Ser. 35, 187-196.

Jensen K.T., Siegismund H.R., 1980. The importance of diatoms and bacteria in the diet of Hydrobia species. Ophelia 1, 193-199.

Kemp P.F., 1986. Direct uptake of detrital carbon by the deposit-feeding polychaete Euzonus mucronata (Treadwell). J. Exp. Mar. Biol. Ecol. 99, 49-61.

Kofoed L.H., 1975. The feeding biology of Hydrobia ventrosa (Montague). I. The assimilation of different components of food. J. Exp. Mar. Biol. Ecol. 19, 233-241. 
Kofoed L.H., Forbes V.E., Lopez G., 1989. Time-dependent absorption in deposit feeders In: Lopez G., Taghon G.L., Levinton J.S. (Eds.), Ecology of marine deposit feeders. Springer, New-York, pp. 128-148.

Lassen H.H., Kristensen J.H., 1978. Tolerance to abiotic factors in mudsnails (Hydrobiidae). Nat. Jutl. 20, 243-250.

Lee J.J., Mc Enery M., Pierce S., Freudenthal H.D., Muller W.A., 1966. Tracer experiments in feeding littoral foraminifera. J. Protozool. 16, 659-670.

Lee J.J., Muller W.A., 1973. Trophic dynamics and niches of salt marsh foraminifera. Am. Zool. 13, 215-223.

Leguerrier D., Niquil N., Boileau N., Rzeznik J., Sauriau P.G., Le Moine O., Bacher C., 2003. Numerical analysis of the food web of an intertidal mudflat ecosystem on the Atlantic coast of France. Mar. Ecol. Prog. Ser. 246, 17-37.

Leguerrier D., Niquil N., Petiau A., Bodoy A., 2004. Modeling the impact of oyster culture on a mudflat food web in Marennes-Oléron Bay (France). Mar. Ecol. Prog. Ser. 273, 147162.

Levinton J.S., 1987. The body size-prey-size hypothesis and Hydrobia. Ecology 68, 229-231.

Levinton J.S., Bianchi M., Stewart S., 1984. What is the role of particulate organic mater in benthic invertebrate nutrition? Bull. Mar. Sci. 35, 270-282.

Levinton J.S., Bianchi T.S., 1981. Nutrition and food limitation of deposit-feeders. I. The role of microbes in the growth of mud snails (Hydrobiidae). J. Mar. Res. 39, 531-545.

Lopez G., Riemann F., Schrage M., 1979. Feeding biology of the brackish-water Oncholaimid nematod Adoncholaimus thalassophygas. Mar. Biol. 54, 311-318.

Lopez G.R., Cheng I.G., 1983a. Epipsammic browsing and deposit-feeding in mud snails (Hydrobiidae). J. Mar. Res. 38, 585-599.

Lopez G.R., Cheng I.J., 1983b. Synoptic measurements of ingestion rate, ingestion selectivity, and absorption efficiency of natural foods in the deposit-feeding molluscs Nucula annulata (Bivalvia) and Hydrobia ulvae (Gastropoda). Mar. Ecol. Prog. Ser. 11, 5562.

Lopez G.R., Kofoed L.H., 1980. Epipsammic browsing and deposit-feeding in mud snails (Hydrobiidae). J. Mar. Res. 38, 585-599.

Lopez G.R., Levinton J.S., 1978. The availability of microorganisms attached to sediment particles as food for Hydrobia ventrosa (Montague) Gastropoda, Prosobranchia. Oecologia 32, 263-375.

Lopez G.R., Levinton J.S., 1987. Ecology of deposit-feeding animals in marine sediments. Q. Rev. Biol. 62, 235-260.

Lorenzen S., 1966. A method for the continuous measurement of in vivo chlorophyll concentration. Deep-Sea Res. 13, 223-227.

Mariotti A., 1982. Apports de la géochimie isotopique à la connaissance du cycle de l'azote. PhD Thesis, Paris, pp. 476.

Meyer-Reil L.A., Faubel A., 1980. Uptake of organic matter by meiofauna organisms and interrelationships with bacteria. Mar. Ecol. Prog. Ser. 3, 251-256.

Moloney C.L., Field J.G., 1989. General allometric equations for rates of nutrient uptake, ingestion, and respiration in plankton organisms. Limnol. Oceanogr. 34, 1290-1299.

Montagna P.A., 1984. Competition for dissolved glucose between meiobenthos and sediment microbes. J. Exp. Mar. Biol. Ecol. 76, 177-190.

Montagna P.A., Yoon W.B., 1991. The effect of freshwater inflow on meiofaunal consumption of sediment bacteria and microphytobenthos consumption of sediment bacteria and microphytobenthos in San Antonio Bay, Texas, U. S. A. Est. Coast. Shelf. Sci. 33, 529-547. 
Moodley L., Boshker H.T.S., Middelburg J.J., Pel R., Herman P., de Deckere E., Heip C.H.R., 2000. Ecological significance of benthic foraminifera: ${ }^{13} \mathrm{C}$ labelling experiments. Mar. Ecol. Prog. Ser. 202, 289-295.

Orvain F., Sauriau P.-G., 2002. Environmental and behavioural factors affecting activity in the intertidal gastropod Hydrobia ulvae. J. Exp. Mar. Biol. Ecol. 272, 191-217.

Pascal P.Y., Dupuy C., Mallet C., Richard P., Niquil N., 2008a. Bacterivory by benthic organism in sediment: quantification using ${ }^{15} \mathrm{~N}$-enriched bacteria. J. Exp. Mar. Biol. Ecol. 355, 18-26.

Pascal P.Y., Dupuy C., Richard P., Niquil N., 2008b. Bacterivory in the common foraminifer Ammonia tepida: isotope tracer experiment and the controlling factors. J. Exp. Mar. Biol. Ecol. 359, 55-61.

Pascal P.Y., Dupuy C., Richard P., Rzeznik-Orignac J., Niquil N., In press. Bacterivory of a mudflat nematode community under different environmental conditions. Mar. Biol.

Porter K.G., Feig Y.S., 1980. The use of DAPI for identifying and counting aquatic microflora. Limnol. Oceanogr. 25, 943-948.

Rice D.L., Rhoads D.C., 1989. Early diagenesis of organic matter and the nutritional value of sediment. In: Lopez G., Taghon G.L., Levinton J.S. (Eds.), Ecology of marine deposit feeders. Springer, New-York, pp. 59-97.

Samir A.M., 2000. The response of benthic foraminifera and ostracods to various pollution sources: a study from two lagoons in Egypt. J. Foraminifer. Res. 30, 83-98.

Schmidt J.L., Deming J.W., Jumars P.A., Keil R.G., 1998. Constancy of bacterial abundance in surficial marine sediments. Limnol. Oceanogr. 43, 976-982.

Schwab D., Hofer H.W., 1979. Metabolism in the protozoan Allogromia laticollaris Arnold. Z. Mikrosk. Anat. Forsch. 93, 715-727.

Severin K., 1987. Laboratory observations of the rate of subsurface movement of a small miliolid foraminifer. J. Foraminifer. Res. 17, 110-116.

Severin K., Erskian M.G., 1981. Laboratory experiments on the vertical movement of Quinqueloculina impressa Reuss through sand. J. Foraminifer. Res. 11, 133-136.

Sokolowski A., Richard P., Fichet D., Radenac G., 2005. Cd transfer in the deposit-feeder prosobranch Hydrobia ulvae (Pennant) from the benthic diatoms: the kinetics of rapid Cd assimilation and efflux. J. Exp. Mar. Biol. Ecol. 317, 159-174.

Sola J.C., 1996. Population dynamics, reproduction, growth, and secondary production of the mud-snails Hydrobia ulvae (Pennant). J. Exp. Mar. Biol. Ecol. 205, 49-62.

Taghon G.L., 1982. Optimal foraging by deposit-feeding invertebrates: roles of particle size and organic coating. Oecologia 52, 295-304.

Taghon G.L., Jumars P.A., 1984. Variable ingestion rate and its role in optimal foraging behavior of marine deposit feeders. Ecology 65, 549-558.

Underwood G.J.C., Kromkamp J.C., 2000. Primary production by phytoplancton and microphytoplancton in estuaries. In: Nedwell D.B., Raffaelli D.G. (Eds.), Estuaries, Advances in Ecological Research. Academic Press, pp. 93-153.

Walton W.R., Sloan B.J., 1990. The genus Ammonia Brünnich, 1772: its geographic distribution and morphologic variability. J. Foraminifer. Res. 20, 128-156. 


\section{Figure captions}

529 Figure 1. Bacteria uptake by $H$. ulvae (mean $\pm \mathrm{SD}, \mathrm{N}=3$ ) as function of incubation time $530(\mathrm{~h})$

531 Figure 2. Bacterial ingestion rate by $H$. ulvae (mean $\pm \mathrm{SD}, \mathrm{N}=3$ ) as function of 532 temperature $\left({ }^{\circ} \mathrm{C}\right)$. Different letters above bars indicate significant differences between 533 incubation conditions (ANOVA; Tukey test).

534 Figure 3. Bacterial ingestion rate by $H$. ulvae (mean $\pm \mathrm{SD}, \mathrm{N}=3$ ) as function of bacterial 535 abundance $\left(10^{8}\right.$ cells $\left.\mathrm{cm}^{3}\right)$. Different letters above bars indicate significant differences 536 between incubation conditions (ANOVA; Tukey test).

537 Figure 4. Ingestion rates of algal carbon $\bigcirc$ (mean \pm SD) and bacterial carbon $\bigcirc$ (mean \pm 538 SD) by $H$. ulvae ( $\mathrm{ngC}$ ind $\left.^{-1} \mathrm{~h}^{-1}\right)$ as a function of algal abundance ( $\mu$ gChla g dry wt sed $\left.{ }^{-1}\right)$. 539 Bacterial abundance was kept constant $\left(1.05 \times 10^{9}\right.$ cells $\left.\mathrm{cm}^{3}\right)$. $*$ above bars indicate 540 significant differences between incubation conditions (ANOVA; Tukey test).

541 Figure 5. Ratio between algae and bacteria taken up by three different grazers (the 542 foraminifera A. tepida, Brouage mudflat nematode community and the gastropod $H$. ulvae) as 543 a function of algal abundance $\left(\mu \mathrm{gChla} g\right.$ dry wt sed $\left.{ }^{-1}\right)$. Bacterial abundance was kept constant $544\left(1.05 \times 10^{9}\right.$ cells $\left.\mathrm{cm}^{3}\right)$.

\section{Table captions}

546 Table 1. Comparison of the feeding activity of three different grazers (the foraminifera $A$.

547 tepida, the Brouage mudflat nematode community and the gastropod H. ulvae). 


\section{Individual weight $\left(\mathrm{gC}_{\text {organic }}\right.$ ind $\left.^{-1}\right)$
Ratio between ingestion rates} of bacteria at 30 and $10^{\circ} \mathrm{C}$ Effect of salinity
(18 against $31 \%$ )

Effect of luminosity (Darkness against $83 \mu \mathrm{M}$ of photons $\mathrm{m}^{-2} \mathrm{~s}^{-1}$ )

$$
1.3 \times 10^{-7}
$$

Effect of environmental factors on ingestion rate of bacteria

\begin{tabular}{|c|c|c|c|}
\hline \multirow{3}{*}{$\begin{array}{c}\text { Effect of salinity } \\
(18 \text { against } 31 \% \text { ) } \\
\text { Effect of luminosity } \\
\text { (Darkness against } 83 \mu \mathrm{M} \text { of photons } \mathrm{m}^{-2} \mathrm{~s}^{-1} \text { ) }\end{array}$} & & & \multirow{3}{*}{$\begin{array}{l}\text { None } \\
\text { None }\end{array}$} \\
\hline & Negative & None & \\
\hline & None & Positive & \\
\hline & \multicolumn{3}{|c|}{ Maximal ingestion rates of bacteria and algae } \\
\hline $\begin{array}{l}\text { Maximal ingestion rate of bacteria } \\
\qquad\left(10^{-3} \mathrm{gC}_{\text {bacteria }} \mathrm{gC}_{\text {grazer }}^{-1} \mathrm{~h}^{-1}\right)\end{array}$ & 0.06 & 0.92 & 7.45 \\
\hline $\begin{array}{l}\text { Maximal ingestion rate of algae } \\
\qquad\left(10^{-3} \mathrm{gC}_{\text {algae }} \mathrm{gC}_{\text {grazer }}{ }^{-1} \mathrm{~h}^{-1}\right)\end{array}$ & 0.94 & 5.08 & 9.56 \\
\hline
\end{tabular}

Table 1 


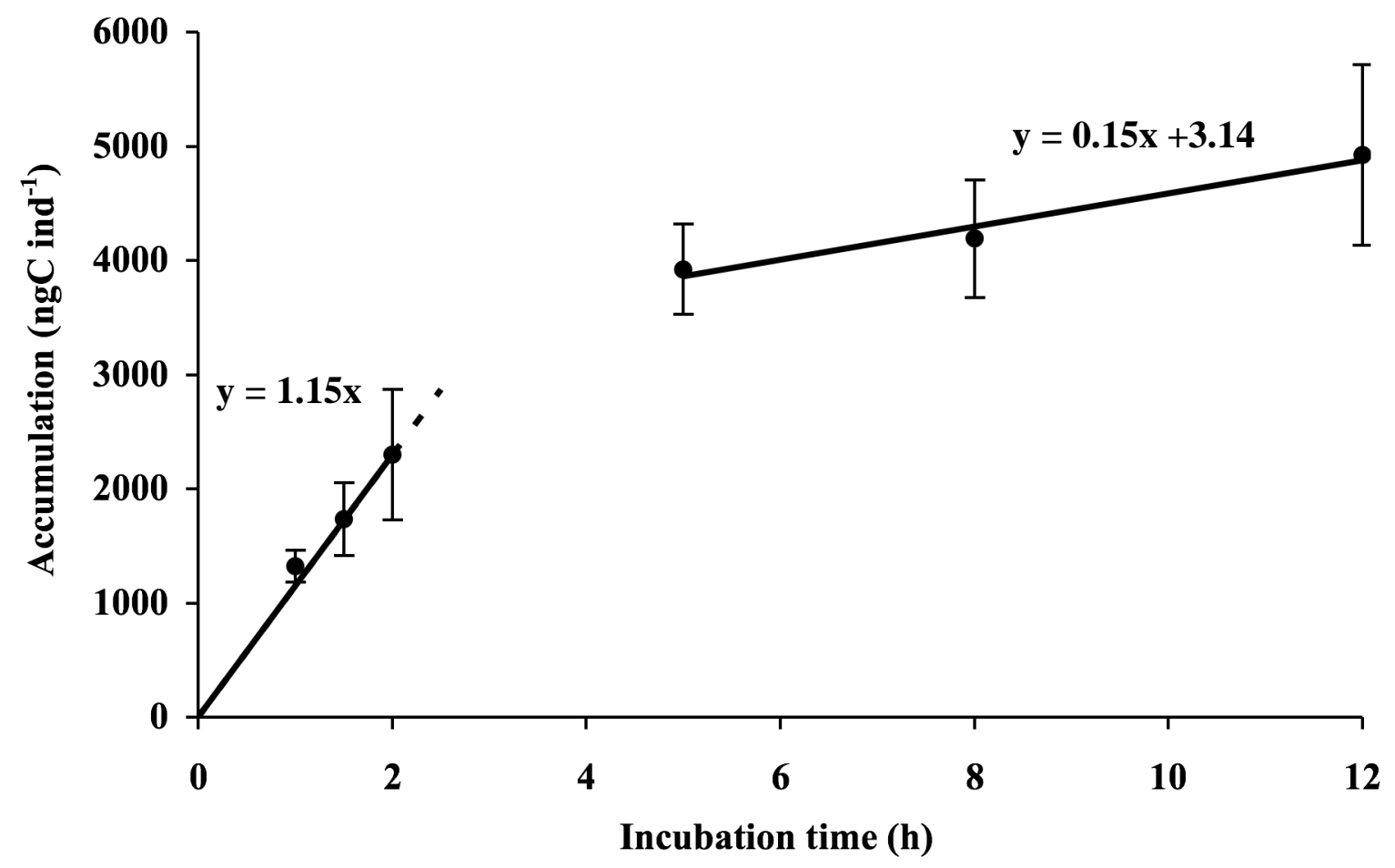

Fig. 1

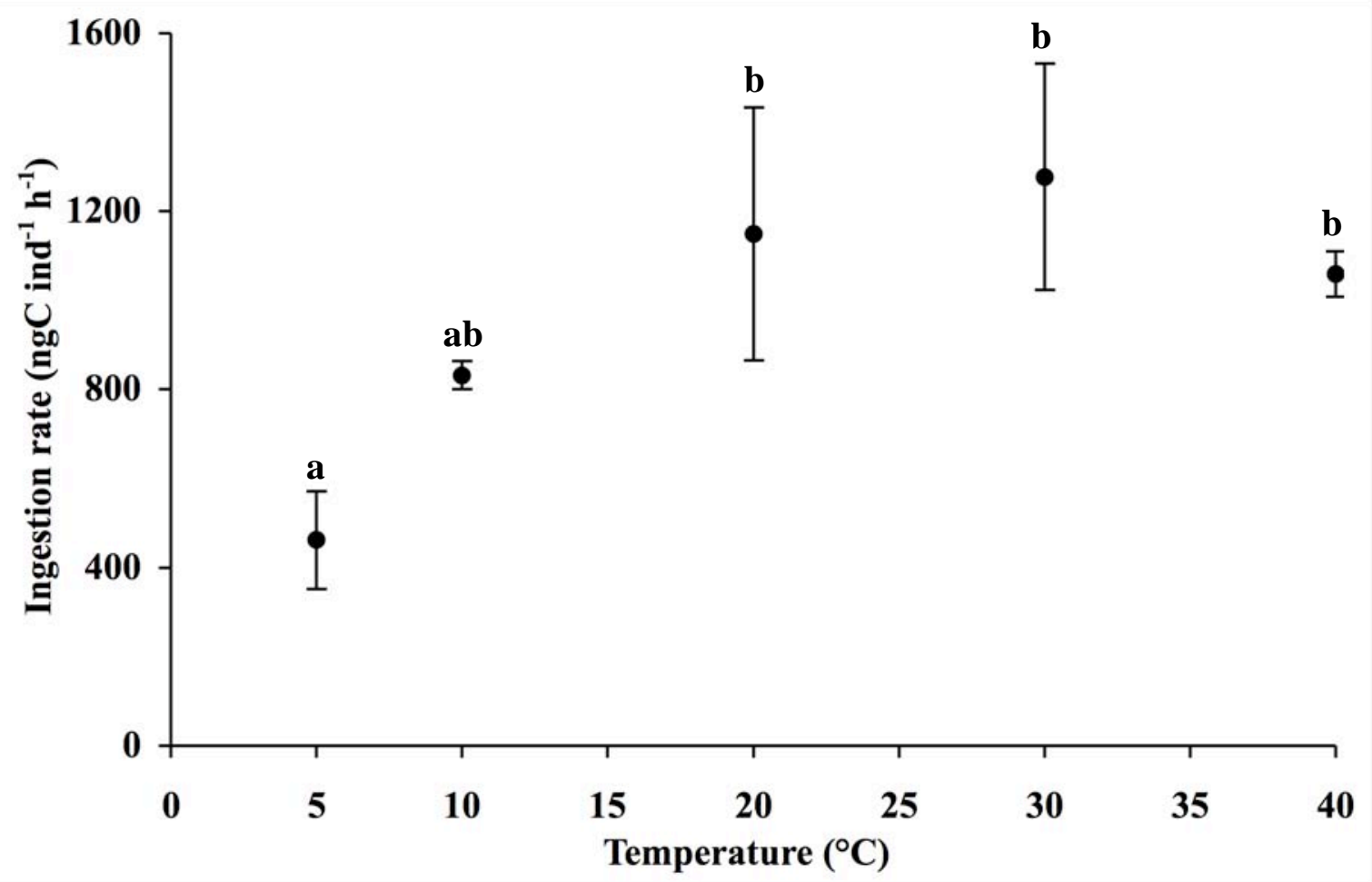

Fig. 2 


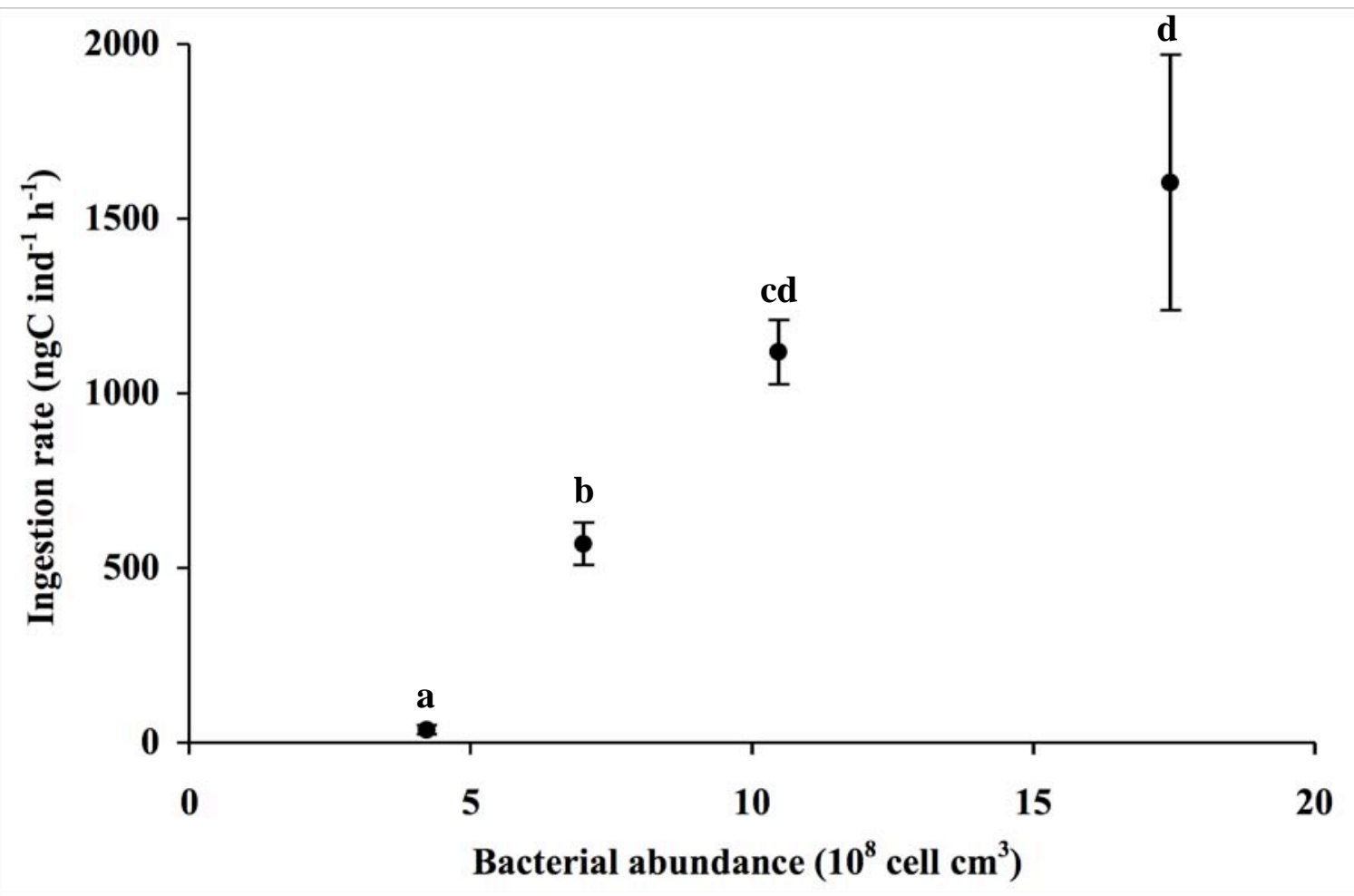

Fig. 3

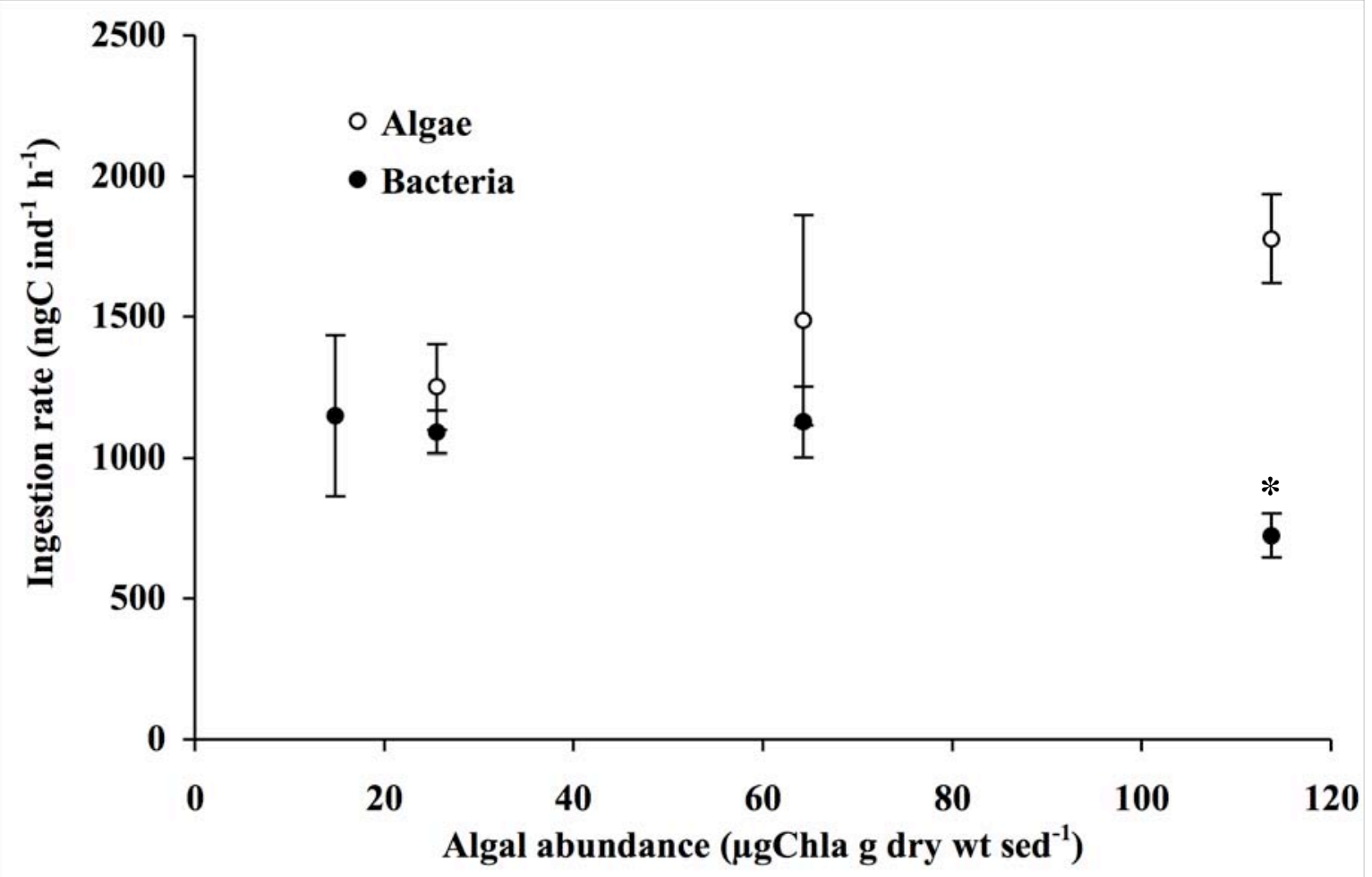

Fig. 4 


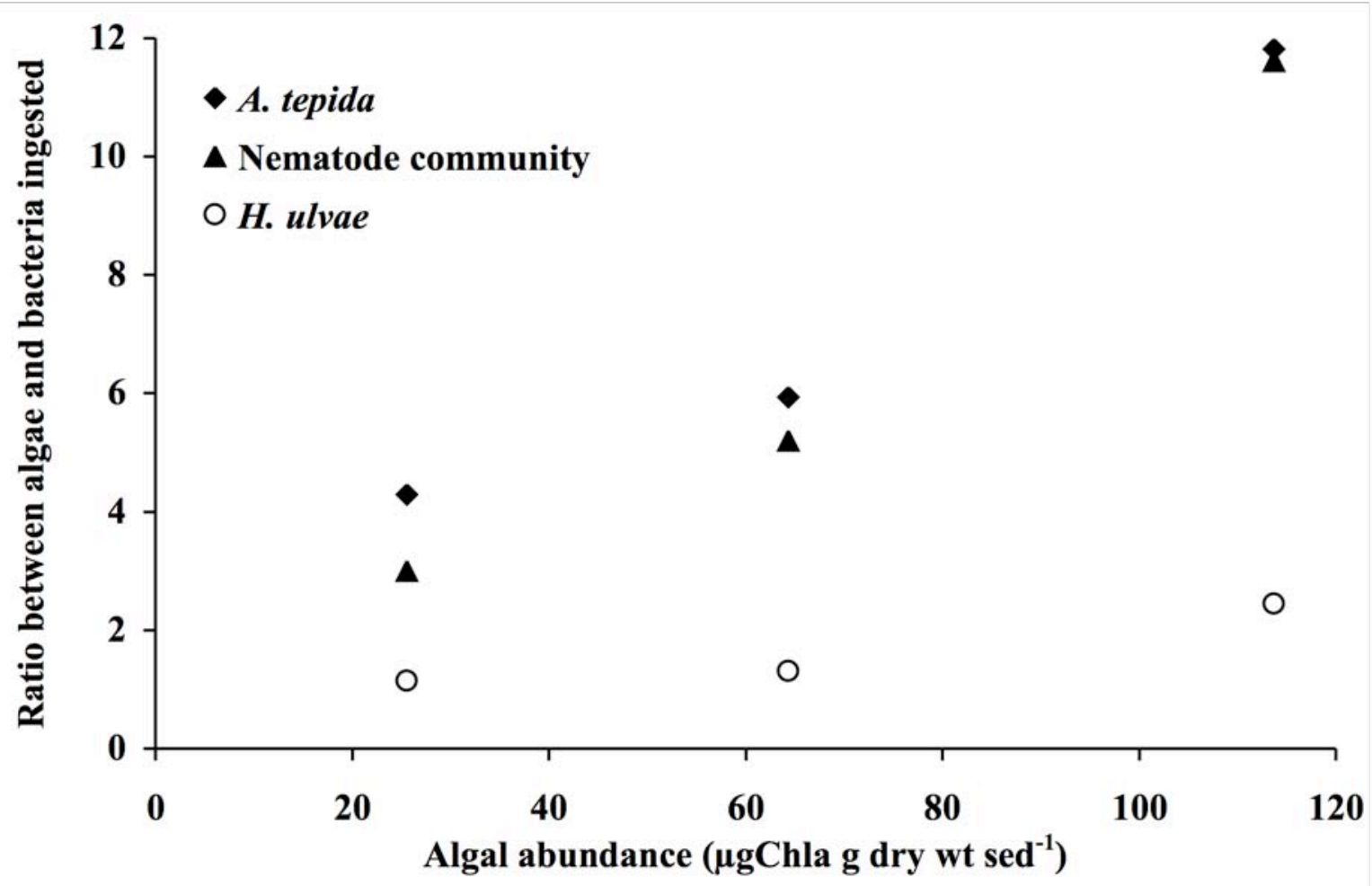

Fig. 5 